\title{
Two Models of the Sanctuary City
}

\author{
Michael Blake
}

ABSTRACT: The increasing political salience of the sanctuary city has not yet been met with adequate philosophical examination of that concept. This article argues that there are at least two models of how the sanctuary city ought to be understood. The first model, the wholesale model, understands the sanctuary city as a standing check against federal overreach; the city ought to refuse to participate in deportation, even when the federal government is morally correct in how and when it deports. The second model, the piecemeal model, understands the sanctuary city instead as one particular site of resistance to particular forms of federal wrongdoing. This article does not seek to vindicate one model over the other, but argues that both models raise significant philosophical worries. More philosophical attention will help us understand both what the sanctuary city is and what might be said in its defense.

KEYWORDS: complicity, deportation, federalism, justice, sanctuary

The concept of the sanctuary city is a not a new one; it is, however, newly important to a great many political debates (Yadoo 2019). Resistance to the migration policies of the Trump administration in the United States has returned the concept of sanctuary to the forefront of public political discourse in that country. The rise of authoritarian populism is a global phenomenon, and activists throughout the world have begun to see the city as a site of resistance against unjust migration law (Galaska 2019; Kassa 2018). Philosophers, however, are only now beginning to examine the concept of the sanctuary city. While many philosophers have sought to apply philosophical methods to larger questions of borders and global poverty (Oberman 2005; Pogge 1997; Van der Linden and Clark 2005), we are only now beginning to examine the more complex and subtle question of when - and how-the sanctuary city is justified (Blake and Hereth 2020; Lenard 2020; Wilcox 2019).

Philosophers are, therefore, still at the beginning of our collective discussions about sanctuary. Our task is made more difficult because of the ways sanctuary is a protean term with a long history; it can be used in distinct ways, by distinct agents, in distinct contexts. The modern use of sanctuary as a political concept is often taken to begin with churches such as Reverend John Fife's Southside Presbyterian Church. Fife opened his church's building in the early 1980s for migrants facing deportation to Central America. Fife's use of the term reflected a lengthy Christian history of sanctuary on which the temporal reach of the secular state could be blocked from physical entry into a religious community's space (Waddle 2008). This religious vision of sanctuary still has political power-a religious community in the Netherlands held a continuous religious service for 97 consecutive days in 2018 to protect an Armenian family from deportation (Mascareñas and Eitel 2019) - but the concept of sanctuary has most recently been adopted 
by political institutions below that of the federal state. The sanctuary movement in the United States has tended to involve an overt refusal on the part of a jurisdictional entity such as a city or a state to offer assistance to the federal agencies charged with deportation (Villazor 2010). In Europe, by contrast, the sanctuary city was until recently understood in less confrontational terms as offering assistance in integration for those migrants accepted by the federal authorities as refugees (Mascareñas and Eitel 2019). Since 2015, however, the sanctuary city in Europe has increasingly started to resemble the more aggressive vision prevalent in the United States. In 2019, for instance, the mayor of Palermo announced he would not permit city employees to comply with the federal law stripping migration status from tens of thousands of immigrants residing in Italy; his justification was that such a law was obviously unconstitutional and any federal demand for participation with this law was therefore without any legal authority (Scarafia 2019). This justification mirrors, to a striking degree, the justification for sanctuary cities, such as Seattle, whose order preventing city employees from complying with any federal request to obtain migration status argued that any federal demand for such compliance was unconstitutional (Seattle City Council Ordinance 121063 2003). ${ }^{1}$

The concept of sanctuary, then, is capable of being understood in distinct ways, and has a long and complex history. For our purposes, though, I want to focus on the city as a particular site of sanctuary; and I will take the core of the sanctuary movement as entailing a principled refusal, on the part of that city's leadership, to permit the city's own authority from being used to assist in the process of deportation. This definition does not exclude the term from being used in distinct modes by other agents, including religious communities or educational institutions; my focus here will be on the city, understood as a jurisdictional subunit engaging in the sorts of refusal described above. The question I want to ask about such cities is simple: what, exactly, is the moral justification for this refusal? The sanctuary city is understood not simply as noncompliance, but noncompliance for a particular moral reason; and I am interested in figuring out how that moral reason might be understood and made precise.

There are, I will argue, at least two broad categories by which this most moderate form of sanctuary city might be defended. They differ, most centrally, in where they look to begin the project of justifying the decision to provide sanctuary. The first category of argument-which I will call the wholesale model-argues that the city should never choose to cooperate with federal authorities in the administration of a program of deportation. ${ }^{2}$ The wholesale model, then, does not depend upon a particularly bad sort of federal policy; the justification for noncooperation is found in any federal system, in which some powers are held by the federal authority and others held by subsidiary units such as the city. The wholesale model, in other words, argues that the city ought to be a sanctuary city, in perpetuity; the circumstances that legitimate the policy of sanctuary are simply those implicit in the practices of federalism and subsidiarity. The second model, which I call the piecemeal model, denies this and grounds the defense of sanctuary in the particularity of what it is the city is being asked to do by that federal authority. This piecemeal model argues that the city has a moral reason to refuse to comply with federal requests when those requests would entail complicity in injustice. The piecemeal model, in short, does not demand that the city ought to be a sanctuary into the indefinite future; the city ought to be a sanctuary, instead, only because the federal government is acting wrongly in how it currently chooses to police its borders and deport those who have crossed those borders without permission. When the injustice ceases, however, so too does the moral justification for sanctuary.

These models are, I believe, often imperfectly distinguished. Take, for instance, the words of Jay Inslee, governor of the State of Washington, in his announcement that his state would henceforth refuse to comply with federal requests for assistance in deportation: "Our state agencies 
are not immigration enforcement agencies ... We will not be complicit in the Trump administration's depraved efforts to break up hard-working immigrant and refugee families" (James 2019).

The first sentence, taken by itself, might seem to argue for a wholesale moral model of sanctuary: the state of Washington should not assist with the process of deportation because it is not set up to do that job well. The second sentence, however, introduces something very much like the piecemeal model: Washington state should become a sanctuary, not because of standing facts about federalism, but because of current (and ideally temporary) facts about federal depravity. That the two models are often conflated is not surprising. In political argumentation, multiple models are sometimes deployed if only to maximize the number of people whose views might be swayed. Political philosophy, however, can perhaps be useful in making these models more distinct and in describing what can be said in favor of each.

This article will therefore not attempt to determine which of these two models is the more likely to succeed. My intention is more schematic than this. I am most interested in what questions we would have to answer for each model prior to resting comfortably with that model as a justification for sanctuary practice. My thesis is therefore rather minimal: I would defend the thought that both of those justifications contain some philosophical difficulty. We have, that is, some rather hard philosophical questions to answer before we can rest easy with either of these visions of what the sanctuary city must be. I think these philosophical difficulties might be answered. I do not want to offer a definitive defense of either model, but neither do I intend to offer a robust condemnation of either. I want one of these models to succeed-to be useful, that is, as a defense of the sanctuary city-as un-philosophical as that might sound. Political philosophers ought to be willing to acknowledge their own moral intuitions, and mine involve a sense that the sanctuary city is, morally speaking, defensible. My only intention in the present context is to examine what we would have to establish before that defense might be made manifest.

One final caveat: I am very much the product of my own legal and political tradition and will generally write from the perspective of someone who lives and does philosophy in the United States. The issue of justice in migration - as with the issue of sanctuary, understood broadly-is an issue that recurs in any number of contexts around the world. If I tend to use examples from my own society, I do this simply because of my own limitations and lack of knowledge-and not because I take that society to be the only one worth discussing. I believe that the moral stories described in this article, while drawn from my particular context, are likely to be present in other contexts. How such stories will vary in those contexts, however, will depend upon the contributions of those who are more knowledgeable about them than myself. My hope is to start a conversation rather than finish one.

With this in mind, we can now proceed to examine the wholesale and piecemeal models of the sanctuary city. How can these models be understood, and what must we know before we can accept those models as justifications for the practice of giving sanctuary?

\section{The Wholesale Model: Sanctuary and Subsidiarity}

The wholesale model, as I have noted, does not depend on particular practices of deportationor, more broadly, of border control-being a part of current federal practice. In this model, the justification for the practice of providing sanctuary must be found elsewhere. One way of getting clear on this model involves assuming that the federal government has arrived at what the defender of sanctuary cities takes to be the best available set of practices of deportation 
and exclusion. Under these circumstances, the wholesale model of sanctuary would still defend the proposition that the city has a moral reason to refrain from cooperating with those federal agents charged with the identification and deportation of city residents.

What reasons, though, could be given in defense of this sort of non-cooperation?

I will ignore, in this context, those who would argue that any practice of deportation necessarily involves injustice. Kieran Oberman and Joseph Carens, for instance, both defend the thought that we have a human right to cross borders and settle where we choose; a federal government that engages in any deportation, then, would be a government that violates the rights of those it deports (Carens 2013; Oberman 2016). I am more interested in those who would defend the thought that some particular sort of deportation would not, itself, be necessarily unjust - and yet that the city ought not to assist the federal government in its efforts to pursue that sort of deportation. What sorts of stories might we provide in defense of that sort of model of sanctuary?

There are, I think, any number of reasons that might be provided to defend the thought that the city should not assist in the federal project of deportation-whether or not that deportation is unjust. ${ }^{3}$ One of these, often cited by the police chiefs of US cities, reflects the simple fact of efficiency in policing (Wexler 2017). Two points are often cited in support of this thought. The first is that the job of policing is difficult enough as it is without adding other tasks to that mix. The city's police are rightly focused on the prevention of crime; their ability to pursue that task becomes more difficult the more they are asked also to police citizenship and residency. The second point, more importantly, argues that effective policing requires the ability to work with the community-including the undocumented (Wexler 2017). When these individuals are less willing to come forward as witnesses or as complainants, the task of responding to crime is made that much more difficult. We can, I think, supplement these reasons with some considerations of how the city and the country are morally distinct. The city, after all, depends largely on people living and working together in geographic proximity. The specific sorts of knowledge of how this sort of community might flourish-or fail to flourish-is generally best held by those who are present within the community rather than outside it. Hence, the general principle that a subject of law ought to be dealt with by the most local jurisdiction capable of responding to it; a federal authority often gets things wrong, when it presumes to know more than the local authorities do about how the local community works. To these ideas we can add one last fact about the nature of membership in the state and in the city. Membership in the state is, at least partly, defined with reference to legal facts of citizenship. Membership in the city, however, is generally ascribed through more informal ideas of residency and social membership. I have not lived in Canada for two decades, for example, but continue to be (legally) a Canadian citizen. I can call myself a Canadian, then, without engaging in serious error. But I cannot call myself a Torontonian; that is not, after all, a legal category; it seems something more like a geographic or social one. Those who emphasize the city's role in responding to global crises often speak of the city as a site of sovereignty (Barber 2017; Cordes 2017). It is worth emphasizing, though, that this sort of sovereignty is rather unlike the sort of sovereignty held by the state under international law. The state is granted both rights and obligations under international law; it can issue passports, draft people into the military, and so on - and it does all of this against a backdrop of international human rights law, which limits what the state can do to its own people (as well as the rights of that state to claim that some people are not its people). The city has nothing akin to this structure. It seems, in short, rather odd and uncomfortable for the city to be put in charge of exclusion on the basis of legal identity. If one does not become a city member because of law, it might be true also that the city should not be the one seeking to sever that membership because of a lack of legal right. 
I believe these ideas, or something like them, are plausible as the basis of a policy of sanctuary. Certainly, they seem to be assumed in some policy discussions-including the various statements given by police organizations against the federal crackdown on sanctuary cities (see Amicus Brief of Current and Former Prosecutors and Law Enforcement Leaders, California v. Sessions 2017). But there is an important worry here, which must be acknowledged by those who defend the wholesale model of the sanctuary city. The worry is that this way of defending the city, since it does not depend on substantive moral principles of justice, is available in principle by any number of city agencies and not simply by those whose political principles we happen to share. The defense is, in other words, content-neutral, and as such we have to understand that the defense might come back to undermine laws many of us might take to be morally defensible.

An example of this can be found in my own home of Washington. In November 2018, Washington voters approved I-1639, which placed substantive restrictions on gun ownership (O'Sullivan 2019). The law raised the age of purchase for a semi-automatic weapon from 18 to 21; directed the state to find a way to check, annually, whether those who possessed handguns and rifles still had the legal right to own such guns; and made unsafe storage of firearms a crime, called "community endangerment." The law itself, naturally, has been the target of intense criticism by the National Rifle Association. Most recently, however, many sheriffs of Washington counties - at least a dozen, at last count-have said that they will not participate in the task given to them under the law. I-1639 requires those sheriffs to participate in figuring out who has guns and whether or not those who have those guns have the right to continue to own them. The sheriffs announcing their non-participation in this law have provided several arguments in defense of their decision. The most common point made is that the law might violate the Second Amendment to the United States Constitution; as such, it is not a valid law, and they have no legal obligation to obey it. The more interesting set of arguments, however, mirror those made above about sanctuary cities and argue that the police of a subsidiary jurisdiction should not use their limited time in working to achieve the policy goals of a superior jurisdiction. John Snaza, sheriff of Thurston County, says as much in defending his ambivalence about enforcing I-1639: "Thurston County is not going to go door-to-door, and neither are the sheriffs you mentioned. I don't really know where any sheriff has the time or the opportunity to do all that to verify ... [I won't] go to every house and ask if they have a person between 18 and 20 who owns a semiautomatic rifle, or where they purchased it" (Rantz 2019).

Sheriff Snaza's response echoes the arguments given about sanctuary cities by police chiefs: the mandate to work for firearm confiscation (like deportation) places burdens on police officers whose job ought to be preventing and prosecuting particular crimes-and, implicitly, that the effort to do this sort of policing will alienate the local population who will react poorly to police agents coming to their door to check on whether or not their firearms have legal status. Others made this link more explicitly: Loren Culp, Police Chief of the town of Republic, Washington, sought unsuccessfully to have Republic declared a "Second Amendment Sanctuary City" (Ricarte 2019).

If the response by the local police here echoes that found in debates about sanctuary cities, so too does the response by the superior political jurisdiction. Attorney General Bob Ferguson has issued a blistering response to the sheriffs' noncompliance, arguing that "enforcement discretion" cannot "subvert the rule of law." Ferguson also sought to threaten the sheriffs into compliance, in terms markedly similar to those used by the Trump administration:

[I]n the event a police chief or sheriff refuses to perform the background check required by Initiative 1639, they could be held liable if there is a sale or transfer of a firearm to a dangerous individual prohibited from possessing a firearm and that individual uses that firearm to do harm. In short, the taxpayers of your city or county assume the financial risk of your deci- 
sion to impose your personal views over the law ... As public officers, our duty is to abide by the will of the people we serve, and implement and enforce the laws they adopt. I encourage you to do so. (Ferguson 2019)

What is the point of this discussion? Not, I think, that one is necessarily a hypocrite if one supports the practice of sanctuary cities and yet condemns the sheriffs who have offered something like sanctuary to gun owners whose rights were altered because of I-1639. One can, perhaps, find a distinction between the cases. The point, instead, is that one has an obligation to do so-to find that distinction, as it were, and explain why it is morally defensible. Otherwise, the problem with the wholesale view of sanctuary is that one may have similar reasons to defend both sanctuary for the undocumented and sanctuary for the 19-year-old owner of a semi-automatic weapon. If there are good reasons for the police of a subsidiary jurisdiction to refrain from helping the authorities of a superior jurisdiction achieve their goals, then those reasons seem to be good ones whether or not we are fans of the law in question. We face, in other words, something like a dilemma, when it comes to the wholesale vision of the sanctuary city. We might seek to find a way of condemning this vision when it defends the sheriff who will not enforce I-1639, while accepting this vision when it defends the sheriff who will not assist Immigration and Customs Enforcement (ICE) in identifying and deporting the undocumented. As I have said above, I think it is plausible that some such distinction might be made. But I am not sure that any such distinction is going to look more like philosophy than special pleading.

Another possible reaction might be to acknowledge that the wholesale defense of sanctuary cities might entail the defense of local policies we might not independently desire. We might, in short, have to regard this sort of defense as available in principle both for liberal causes and for conservative ones. There is nothing, I think, wrong with this; a great many things- up to and including freedom of speech or freedom of association-offer support both for causes we support and for those we abhor. Most of us who respect the right to freedom of speech accept that this entails freedom for those whose speech is horrific. We accept the right, if we do, with due understanding that the right brings costs as well as benefits. It seems plausible that something similar might be true about the wholesale vision of the sanctuary city. We might conclude that the sanctuary city is defensible and the wholesale account offers the best defense. We should not conclude that this sort of defense is only susceptible of use by those whose values we share. ${ }^{4}$

\section{The Piecemeal Model: Sanctuary and Speech}

If the wholesale model brings with it certain costs, we might see if the piecemeal model fares somewhat better. The piecemeal model begins with the thought that the city is permitted to refrain from assisting in deportation because that deportation-or, more broadly, the set of institutions and practices giving rise to that deportation-is unjust. The refusal to participate, then, is not a blanket refusal to offer help to the agents and institutions of the federal government, but a specific response to specific forms of injustice.

The power of this model might be seen in the fact that the resurgence of interest in sanctuary in the United States has come along with rise of Donald Trump. Trump, after all, announced his candidacy with a speech excoriating Mexican migrants as rapists and murderers; sought to eliminate the Obama-era program offering deferred removal to undocumented residents brought here as children; sought to ban migrants from certain specified countries, largely but not exclusively majority-Muslim; granted a pardon to Sheriff Joe Arpaio for his program of racial profiling in Arizona; sought to make migrants who have relied on public benefits deport- 
able by virtue of that fact; and continues to seek funding for a wall between the United States and Mexico (Lopez 2019). For a great many people-myself included-this pattern of actions has been worrying. Donald Trump's willingness to demonize prospective migrants, coupled with his administration's willingness to countenance the deportation of migrants already here, has led to a pattern of deeply unjust laws and policy responses. The sanctuary city might, then, be defended as a particular response to this particular set of circumstances.

I am, in the present context, not especially interested in establishing that the policies of deportation under consideration are unjust. I am more interested in understanding how the conclusion that they are unjust can be used to ground the conclusion that the sanctuary city is morally right. One immediate rejoinder, here, is that the belief that a law is unjust does not rob us of the obligation to obey that law-either in law or in morality. As Bob Ferguson notes in his letter to the sheriffs of Washington: the fact that he was and is passionately opposed to the death penalty did not rid him of the obligation, as Attorney General, to administer and apply the penal system of Washington State. So, too, we might think that the fact that the federal policy is unjust might not provide any cover for the subsidiary agency seeking to avoid participation with that policy.

This immediate rejoinder is subject to a number of worries. The first of these is whether or not the sanctuary city is, in fact, engaging in disobedience at all. Patti Tamara Lenard, elsewhere, has defended the thought that the city's noncompliance with federal authorities is not disobedience, given the lack of an explicit mandate through which compliance might be justified; nor is it necessarily an attack upon the federal government's right to exclude and deport, given that the sanctuary city does not itself make it impossible for the federal government to police the borders of the state (Lenard 2020). The sanctuary city, then, might not be always disobeying, but rather refusing to let its own jurisdictional powers be seized by the federal government; the law of the United States provides the city with some grounding for this refusal under the heading of the anti-commandeering principle (Adler 2001). In this way, the city represents a site of resistance, one of the many sites that might work toward reinterpreting and recasting the supposedly dispositive pronouncements of a federal authority (Dennler 2018). A second, broader, worry goes toward the issue of disobedience and notes that we might be able to justify disobedience to an unjust law by collective agents, as much as we have by individuals. We have, in other words, a long-standing tradition of civil disobedience, by which individuals are able to justify a refusal to accept legal commands, in response to the injustice of those offering the commands. The piecemeal defense of the sanctuary city might require us to adapt this sort of defense to the specific circumstances of the one offering the disobedience. But there is no reason such a defense is not in principle available.

What I am more interested in, though, is what the point of the sanctuary city is when the policy of sanctuary is understood as a response to significant political wrongdoing on the part of the federal government. What, in short, is the city trying to do by refraining from participation with the federal government? This question is distinct from the legal question of whether or not the disobedience is one that violates Constitutional norms; and it is this question that might need some amplification-and I suspect that any answer that we might offer could give rise to questions that might prove difficult to answer.

I believe there are, at the very least, three possible things that the sanctuary city might be trying to do by publicly refusing to assist the federal government in its practices of deportation. It might be seeking to frustrate that policy to make the federal government less able to do injustice in the world. It might be seeking to speak about such policy and offer a political statement about the injustice it represents. Or it might simply be pursuing ethical purity and trying to avoid being causally implicated in a significant injustice. I suspect that any existing sanctuary 
city might be trying to do all of these at once; but each of them has its own difficulties and figuring out which of these is most important is necessary before we can continue to think that the sanctuary city is a correct policy tool for the city to deploy.

Let's imagine that the first thing the city is trying to do is make it difficult for the federal government to engage in serious wrongdoing. The city becomes convinced that the federal jurisdiction is wronging people through its practices of deportation; as such, it announces a policy of sanctuary to work against the federal government's ability to do this sort of wrong. This is a plausible basis for the sanctuary city but, as with all of these bases, it brings with it certain important questions. The first of these, as above, is with the identification of when and how we are right to stop the administration of unjust law. If the law is unjust, after all, we still need a story about when and how we are right to frustrate those who administer it. To use Ferguson's example: if I believe that the death penalty is illegitimate, it does not follow that I can simply refuse to enact it while continuing to serve as Attorney General. A crucial part of the story might be whether or not the city is actively trying to frustrate the policy-or simply refraining from offering its own power in defense of that policy, as Lenard argues. What I find more interesting, though, is the question of whether public non-participation is the most effective way of undermining the ability of the federal government to do wrong. It is certainly not the only sort of tool a city might use; and it is not clear - to me, at any rate - that it is the most likely to do the job. One question might be whether or not the city has a right to engage in private non-participation. Sanctuary cities, for the most part, call themselves that and announce their non-participation. It might be the case, however, that sometimes the most effective response to injustice is not to announce that one is working against it, but simply to undermine that injustice, quietly and vigorously. We might also ask whether or not something more than non-participation-including, perhaps, such practices as active deception or providing privileged information to the undocumentedmight be more effective. Why think that publicly refusing to help deportation is more effective than, say, quietly providing undocumented residents with good information about federal actions while providing federal agents with bad information at the same time?

I think many people will react badly to these thoughts; there is something more morally serious about lying and leaking than there is about public non-participation. But if the point of the sanctuary city is to stop a particular injustice in the world, then we have a right to expect some story about when and where this more extreme sort of method might be used. This sort of moral story, in short, is not necessarily wrong, but it is incomplete, and we are entitled to a longer story about why these practices are the sorts that ought to occupy our attention.

We can then proceed to the second sort of story. In this account, the sanctuary city is intending to speak through its noncompliance with federal authority. It may or may not want to do something when it refrains from acting in concert with federal authorities; but it certainly wants to say something, which is that the federal government is wrong in what it proposes to do. The point of the sanctuary is to speak and to bring about a wider and more responsive discourse within which the injustice currently found is eliminated.

This is a powerful idea. I think that it, too, might require us to give more of a story about political speech than we usually do. One topic that might be required is fairly simple: when may collectives, such as cities, give themselves the right to speak? Certainly the people within those cities may speak; freedom of speech, if it means anything, means that the inhabitants of cities might have the right to condemn (or defend) government policy. But what is happening instead is that the city itself is speaking-and speaking as a city. It is speaking for, as it were, the set of people within that city but speaking through its own voice. I do not think that this is, in itself, morally wrong. Certainly, cities-like states-do a great many things that are discursive in nature. But there are questions that have to be asked about when and how cities might 
speak-and when they should simply accept a judgment made elsewhere, whether or not that judgment is just.

Take, for instance, the 2014 vote in the Louisiana House of Representative to keep a state law against sodomy on the books (Morrison 2014). The law was, of course, unconstitutional after Lawrence v. Texas, a decade earlier, struck down such laws. The House, however, wanted to use the law to make a discursive point: that they were still opposed to same-sex intimacy and wanted the other states (and gay citizens of Louisiana) to be aware of that hostility. I suspect most people reading this article are opposed to the law itself. What might be more interesting is our reaction here-not to the law, but to the decision to use the power of the state to make this sort of discursive point. Some people-myself among them-might think that it is at the very least unsettling to use the power of the state of Louisiana to make this sort of philosophical point. If one is banning gay sex, it should be because one wants to ban gay sex and not because that is the nearest available canvas on which to inscribe one's hostility to gay sex. So, too, with the discursive vision of the sanctuary city. If one is hostile to the Trump administration's attitude toward migrants - and I am - then one might nonetheless want to know more about why this is the best available forum within which one might speak back against that attitude. At the very least, one is entitled to hear a bit more about what it is that constrains and informs the right of a city or a state to use its policy not to do things, but to say things.

I should be clear that I am not opposed to the possibility that the best justification for the sanctuary city is discursive. I do not want to say that. I want, instead, to argue the more moderate point that we are entitled to hear more about why this particular sort of non-participation represents the appropriate means by which this sort of speech might be communicated. I am interested, in short, in figuring out why the state (or the city) is allowed to do this sort of thing; not in saying that it is not. ${ }^{5}$

The same holds true for the last of the possible stories we might provide for the moral point of the sanctuary city. This is the simple moral story of non-participation; the city, we might think, intends to avoid becoming complicit in evil and so will not lend its own powers to the administration of a policy that is fundamentally immoral. My own view, for what that is worth, is that this is the most defensible basis for the policy of sanctuary; this, however, does not mean that this story does not stand in need of some significant philosophical unpacking.

The reason for this is that usual response to injustice is not simply noncompliance, but active resistance. When one is facing a predatory or evil state, for instance, we tend to think that the best response involves active work against that state-rather than simply a refusal to participate. We are, we might think, obligated to hurt that state rather than simply refrain from helping it. The refusal to participate, instead, seems most appropriate when what it at issue is not a grave injustice, but something more like an assault on one's integrity. To take an example from Bernard Williams: I have moral permission to refrain from working on chemical weapons, even if I know that the person who will take the job if I refuse it is unreasonably energetic and good at building those weapons. That is because-for Williams-I am not obligated, in the name of justice, to do whatever makes the world have the fewest chemical weapons in it; I am entitled to keep my hands clean, even if that makes the world slightly dirtier than it would otherwise be (Williams and Smart 1973). But does this sort of story track the moral perspective of the city in face of morally unjust federal policies of deportation?

If it does, we might have to unpack why it does. In the first instance, we might think that the refusal to become causally implicated in injustice works because individual people understand themselves to be agents with a certain notion of integrity and self-respect as such. (Certainly, that is Williams's take on these issues.) We might have to figure out whether notions such as these can be meaningfully applied to cities or to other forms of collective political body. But we 
might also have a right to hear why the city should not be required to do more than this. If I believe that a given policy is unjust, I have a reason to work against that policy; it does not simply give me a reason to refrain from helping those who administer it. If the city is trying to keep its hands clean, in short, we have a right to know what those hands are and why their cleanliness is more important than the individuals subject to unjust deportation.

I would end this article by returning to the note I made at the beginning: I do not want anything I say here to be viewed as either a defense or a critique of the sanctuary city as that entity is understood in contemporary politics. I am more concerned with making the point that our best understandings of the sanctuary city give rise to important questions-questions, most notably, about what the purpose of the sanctuary city is and how that purpose might be fulfilled. I will therefore be happy if I have shown enough to suggest that these questions must continue to be raised and debated in forums such as this journal.

MICHAEL BLAKE is Professor of Philosophy, Public Policy, and Governance at the University of Washington. He is jointly appointed to the Department of Philosophy and to the Daniel J. Evans School of Public Affairs. His most recent book is titled Justice, Migration and Mercy (Oxford University Press, 2019). E-mail: miblake@uw.edu

\section{NOTES}

1. I would note, finally, that there is some nascent movement to regard some cities in the global Southsuch as, notably, Amman - as cities of refuge and therefore as potential sanctuary cities as well (Mascareñas and Eitel 2019). Resistance to this usage has noted that the profound differences between the role of Amman in defending the rights of refugees and the role of wealthy cities such as Seattle or Palermo; we risk ignoring these differences when we use the same conceptual framework in both contexts. For the purposes of this article, I will use the term sanctuary city to refer only to cities in the Global North whose self-description as sanctuary cities entails resistance in some form to federal practices of deportation.

2. The use of "federal" here does not imply any concept unique in applicability to the United States or other explicitly federal states; instead, it means only to mark out the relationship between a legally superior jurisdictional space and a legally inferior one. The question facing cities in European states might be usefully understood through this lens of cooperation and non-cooperation, even if the state is not explicitly a federal system.

3. Patti Lenard and Audrey Macklin have both suggested that one additional important reason might be the desire of the city for a place at the table, especially when the city is being asked to participate in the administration of federal law. This seems right, but whether it suffices as a reason would depend upon when this particular way of insisting upon that place is morally right.

4. An additional possibility, which I do not discuss here, comes from Shelley Wilcox, who argues that sanctuary policies might be justified with reference to public safety and harm reduction. Wilcox's argument deserves more space than I can give it here-but I can at least note that any argument from harm must involve not only a judgment about harms, but also a judgment about who is allowed to say which policy is likely to determine harm. Given that all parties to these disputes-with regard to both firearms and migration-use consequentialist reasoning, the question that must be asked is whose judgments ought to be preferred, when there is conflict. See Shelley Wilcox (2019).

5. Mette Louise Berg has urged me to differentiate, at this point, between the city and the state; the city, in particular, has a long history of being accommodating to those seeking refuge at its gates, as is noted in Elena Isayev's analysis of hospitality (Isayev 2018). I believe she is right to so insist, and 
indeed the particular history of the city might be a necessary part of the analysis here of the discursive politics of the city. My primary purpose, however, is in noting that some such defense of the rightness of this jurisdictional entity giving this particular political sort of discourse. I think the history of the city might well form the basis of that sort of defense, but I do not want, in the present context, to commit myself to any particular account of how it might do so. I am grateful to Berg for her conversations on this subject.

\section{REFERENCES}

Adler, Matthew D. 2001. "State Sovereignty and the Anti-Commandeering Cases." Annals of the American Academy of Political and Social Science 574 (1): 158-172. https://doi.org/10.1177/00 0271620157400112.

Amicus Brief of Current and Former Prosecutors and Law Enforcement Leaders, California v. Sessions. 2017. https://www.law.georgetown.edu/icap/wp-content/uploads/sites/32/2018/06/California-vSessions-brief.pdf.

Barber, Benjamin. 2017. Cool Cities: Urban Sovereignty and the Fix for Global Warming. New Haven, CT: Yale University Press.

Blake, Michael, and Blake Hereth. 2020. "Sanctuary Cities and Non-Refoulement." Ethical Theory and Moral Practice 23 (2): 457-474. https://doi.org/10.1007/s10677-020-10082-3.

Carens, Joseph H. 2013. The Ethics of Immigration. Oxford: Oxford University Press.

Cordes, Vojislava Filipcevic. 2017. "City Sovereignty: Urban Resistance and Rebel Cities Reconsidered." Urban Sciences 1 (3): 1-23. https://doi.org/10.3390/urbansci1030022.

Dennler, Kathryn Tomko. 2018. "Re/Making Immigration Policy through Practice: How Social Workers Influence What It Means to Be a Refused Asylum Seeker." Migration and Society 1 (1): 82-95. https://doi.org/10.3167/arms.2018.010108.

Ferguson, Robert. 2019. “Open Letter to Washington's Sheriffs and Police Chiefs Refusing to Enforce Initiative 1639.” Washington State Wire, 13 February. https://washingtonstatewire.com/ag-fergu son-addresses-sheriffs-refusing-to-enforce-i-1639/.

Galaska, Jascha. 2019. "Sanctuary Cities Challenge Restrictive Migration Policies." Liberties EU, 13 February. https://www.liberties.eu/en/news/sanctuary-cities/16982.

Isayav, Elena. 2018. "Hospitality: A Timeless Measure of Who We Are?” Migration and Society 1 (1): 7-21. https://doi.org/10.3167/arms.2018.010103.

James, Tom. 2019. "Washington Joins West Coast Bloc of Sanctuary States." AP News, 22 May. https:// apnews.com/92bba0d74e05499fb5397fbb431069fa.

Kassa, Derese. 2018. Refugee Spaces and Urban Citizenship in Nairobi. Washington, DC: Lexington Books.

Lenard, Patti Tamara. 2020. "The Ethics of Sanctuary Policies in Liberal Democratic State." In The Political Philosophy of Refuge, ed. David Miller and Christine Straehle, 231-251. Cambridge: Cambridge University Press.

Lopez, German. 2019. “Donald Trump’s Long History of Racism, from the 1970s to 2019.” Vox, 15 July. https://www.vox.com/2016/7/25/12270880/donald-trump-racist-racism-history

Mascareñas, Blanca Garcés, and Kristen Eitel. 2019. “Sanctuary Cities: A Global Perspective." CIDOB: Barcelona Center for International Affairs. https://www.cidob.org/en/articulos/anuario_inter nacional_cidob/2019/sanctuary_cities_a_global_perspective.

Morrison, Sara. 2014. “Louisiana Won't Get Rid of its Unconstitutional Sodomy Ban.” The Atlantic, 15 April. https://www.theatlantic.com/national/archive/2014/04/louisiana-wont-get-rid-ofits-unconstitutional-sodomy-ban/360727/.

Oberman, Kieran. 2015. “Poverty and Immigration.” American Political Science Review 109 (2): 239-251. https://doi.org/10.1017/S0003055415000106

Oberman, Kieran. 2016. "Immigration as a Human Right." In Migration in Political Theory, ed. Sarah Fine and Lea Ypi, 32-56. Oxford: Oxford University Press. 
O'Sullivan, Joseph. 2019. "New Washington Gun Regulations Become Law, as Resistance Hangs over Initiative 1639." Seattle Times, 30 June. https://www.seattletimes.com/seattle-news/politics/ new-washington-gun-regulations-become-law-as-resistance-hangs-over-initiative-1639/.

Pogge, Thomas. 1997. "Migration and Poverty." In Citizenship and Exclusion, ed. V. Bader, 12-27. London: Palgrave Macmillan.

Rantz, Jason. 2019. "Thurston Sheriff on 1639: 'Am I Supportive of It? No. Am I Going to Enforce It? Yes."' My Northwest, 6 February. https://mynorthwest.com/1264445/thurston-sheriff-initiative$1639 /$.

Ricarte, Raelynn. 2019. "Some Sheriffs Say Voter-Approved I-1639 Violates 2nd Amendment." Chinook Observer, 6 February. https://www.chinookobserver.com/news/state/some-sheriffs-say-voterapproved-i-violates-nd-amendment/article_e49a7046-2a73-11e9-905e-573befe4345e.html.

Scarafia, Sara. 2019. "Palermo: folla in piazza contro il decreto sicurezza." La Repubblica, 4 January. https://palermo.repubblica.it/cronaca/2019/01/04/news/palermo_folla_in_piazza_contro_il_ decreto_sicurezza_orlando_e_l_arcivescovo_attaccano_il_governo-215809027/?refresh_ce.

Seattle City Council Ordinance 121063. 2003. http://clerk.ci.seattle.wa.us/search/results?d=CBOR\&s1 $=114436 . \operatorname{cbn} . \&$ Sect $6=$ HITOFF $\& \mathrm{l}=20 \& \mathrm{p}=1 \& \mathrm{u}=/ \sim$ public $/$ cbor $2 . \mathrm{htm} \& \mathrm{r}=1 \& \mathrm{f}=\mathrm{G}$.

Van der Linden, Harry, and Josh Clark. 2005. "Economic Migration and Justice." International Journal of Applied Philosophy 19 (1): 45-61. https://doi.org/10.5840/ijap20051912.

Villazor, Rose Cuison. 2010. "Sanctuary Cities' and Local Citizenship." Fordham Urban Law Journal 37 (2): 573-598. https://ir.lawnet.fordham.edu/cgi/viewcontent.cgi?article=2338\&context=ulj.

Waddle, John. 2008. "No More Deaths: An Interview with John Fife." Reflections: A Magazine of Theological and Ethical Inquiry from Yale Divinity School. https://reflections.yale.edu/article/ who-my-neighbor-facing-immigration/no-more-deaths-interview-john-fife.

Wexler, Chuck. 2017. "Op-ed: Police Chiefs across the Country Support Sanctuary Cities Because They Keep Crime Down.” Los Angeles Times, 6 March. https://www.latimes.com/opinion/op-ed/ la-oe-wexler-sanctuary-cities-immigration-crime-20170306-story.html.

Wilcox, Shelley. 2019. “How Can Sanctuary Policies be Justified?” Public Affairs Quarterly 33 (2): 89-113. https://doi.org/10.2307/26910021.

Williams, Bernard, and J. J. C. Smart. 1973. Utilitarianism: For and Against. Cambridge: Cambridge University Press.

Yadoo, Jordan. 2019. "Your Questions about Sanctuary Cities, Answered." Washington Post, 18 April. https://www.washingtonpost.com/business/your-questions-about-sanctuary-cities-answered/ 2019/04/16/19177d5a-6052-11e9-bf24-db4b9fb62aa2_story.html. 